\title{
Charcoal Enterprise in Benin City, Edo State, Nigeria
}

\author{
KALU, C; IZEKOR, D N \\ Department of Forestry and Wildlife, Faculty of Agriculture, University of Benin. P.M.B.1154 Benin City Nigeria.
}

\begin{abstract}
Charcoal enterprise has been adopted to meet some socio-economic benefits and energy needs of the people. The study was conducted to determine peoples' involvement, uses and reasons for using charcoal, distribution channel as well as weekly sales and profit of the enterprise. The results revealed that people involved in sales of charcoal were $28.26 \%, 9 \%$ and $2 \%$ of the respondents for Igun Street, Oba market/New Benin and Ikpoba Hill market respectively. The identified uses of charcoal were for roasting of maize (32. $75 \%)$, Suya preparation and cooking of food accounted for $13.70 \%$ and $16.13 \%$ respectively, while Black Smiting and Bronze casting accounted for $13.70 \%$ of the respondents. ANOVA indicated that there were no significant differences $(\mathrm{P}>$ 0.05 ) among the identified reasons for using charcoal as well as the weekly sales of the product. However, distribution channel of charcoal showed significant difference $(\mathrm{P}<0.05)$ with dominant retail channel revealed using fishers least significant difference (LSD). The weekly profits of over N2,000 were confirmed by $48.48 \%$ and $24.24 \%$ of the respondents for the rainy and dry seasons respectively. Research effort in charcoal enterprise needs to be focused in order to ensure sustainable development and realization of the desired potential of the enterprise. @JASEM
\end{abstract}

A Charcoal is just a piece of word with messy and dangerous parts baked off; often it has additives like borax, nitrate and lime (Holmes, 1998). Though, the conventional method of charcoal making has no means of recovering of heat waste, charcoal is probably a more efficient cooking fuel than wood (NRI, 1992). This is because $50 \%$ energy loss associated with the production of charcoal from wood is more than compensated by the much higher fuel efficiencies obtained in burning charcoal as cooking fuel. Bulaghsingala (1983) has noted that charcoal stove has fuel efficiencies of $25-35 \%$ whereas wood stove is about $10 \%$ efficient.

Charcoal enterprise as well as other endeavour concerning renewable energy sources is an important aspect of rural economies. This is because domestic energy consumption is the major component of economies of most sub-Saharan Africa (Engelhard, 1992). Petroleum -based energy such as liquefied natural gases $(\mathrm{LNG})$ and kerosene are regularly used and sold in Benin City and its adjoining villages. However the scope for other forms of renewable energy is limited due to lack of technological break through and invention. Thus, charcoal remains the most important source of energy for domestic and small scale commercial processing and food preparation namely: suga, roasting of yam, maize, plantain etc. This is a regular feature in most streets and some eating joints and restaurants in the cities.

The ever rising human population and its associated demand have put pressure on the supply of the product. In fact, charcoal supply is failing to meet the demand of the users especially during the raining season. This is because charcoal making is still at traditional stage. It is also because charcoal making is labour intensive and involves burning away energy in the baking process (Holmes, 1998). Therefore, the output and supply of the products to the traders and ultimate consumers are affected. Invariably, the price per given volume rises. The seasonal charcoal shortages spin-off unavailability and make the product relatively unaffordable which adversely affect the ability of most consumers to purchase the product regularly. The charcoal enterprises are predominantly carried out by the women. This is not to attest the long standing strict division of responsibility between men and women in (least developed countries) LDCs where women are expected to fetch fuel wood. In deed the marketing activities are to generate cash to satisfy basic needs and social investment like school fees, medical bills etc. The enterprise is under taken by the low income group of the population which assists toward alleviating of poverty level as well as self sufficiency.

However, the desired values from the charcoal business are not always realized is due to the imperfect marketing of the product. The buyers and sellers do not have perfect knowledge of the price. The reason is because the consumer (buyer) can not afford the time to go to all the sheds in the various markets to compare price everyday (Harvey, 1991) Thus, it adversely affects the fortune of the enterprises or the returns.

This paper specifically assesses the number of people involved in charcoal enterprise, weekly sales, uses of charcoal energy and reasons for opting for the product and the marketing channel. It will in a large extent assist in solving fuel crisis especially during the scarcity of petroleum products which occur regularly and always take people by surprise.

\section{METHODS}

The study area of the research is Benin City which is the commercial and political nerve of Edo State. The state situates in South-Western Nigeria and is dominated by the moist tropical forest. The state is 
endowed with timber species suitable for charcoal production such as Penterclethra macrophylla, laphira alata, Cylieodiscus gabunensis Piptadeniastrum africanum, Rhizophora recemosa, Rhizophora harrisonii..In the state, low land rain forest represents $76.5 \%$ of the total lard area (FORMECU, 1999). It lies approximately between longitude $5^{\circ}$ and $6^{\circ} \mathrm{E}$ and between latitudes $5^{\circ}$ and $6^{\circ}$ $30 \mathrm{~N}$.

The climate is tropical high rain forest with rainfall occurring between March and October. The average annual rainfall is $2052.4 \mathrm{~mm}$ with an average temperature of $27^{0} \mathrm{C}$. These weather conditions account for availability of charcoal in most of the markets throughout the year. However, there are variations in prices as well as available volume of the product from one season to another (dry and raining season) due to differences in volume available for sale.

Sampling method: A pilot survey was carried out in Benin City to identify the charcoal sellers as well as the villages where the product is obtained. The distributions of charcoal sellers in the city were identified prior to questionnaires administration.

Random sampling was used to select the number of people involved in charcoal market enterprises viz, charcoal sellers and consumers six markets and the adjoining streets in Benin City where charcoal was predominantly sold. The locations were: Uselu, New Benin, Oba, Oliha Ikpoba Hill, Ogiso and markets and Igun street.

A total of 90 structured questionnaires were administered to the charcoal sellers in all the locations in the study area while a total of 46 copies were retrieved. The distribution of administered questionnaires to the respondents was based on $80 \%$ sampling intensity. In the case of consumers/users of charcoal, 20 copies of questionnaires were randomly administered in each location and the adjoining street. Personal interview as well as the administration of the questionnaires was carried out by the researcher and the field assistants to ensure that adequate representative of all nooks and carnies of the locations under review were surveyed.

Data collection and Analysis: Data were carefully scrutinized before collection to ensure that reliable information was obtained. The collection of the data from the seven locations was carried out using Hannagan's method (1980) of coding in processing of questionnaires. The coded information were classified and summarized in form of Tables. These summarized data were analysed using simple percentage and analysis of variance (ANOVA) which were appropriately applied to the data in various tables.

\section{RESULTS AND DISCUSSION}

The results indicated the number of people who depended on charcoal enterprises in order to meet the basic needs of their respective lives. (Table 1). There were variations in the results obtained in the various locations considered in the study. The result obtained from Igun street dominated other locations which accounted for $28.6 \%$ which was distantly followed by $\mathrm{Oba}$ and New Benin markets which accounted for $19.57 \%$ equally. Least values were observed in Oliha and Ikpoba Hill markets which accounted for $6.52 \%$ and $4.36 \%$ respectively.

Table 1 Number of people involved in charcoal enterprises.

\begin{tabular}{|l|l|l|}
\hline Mkts & Frequency & Percent \\
Oba & 9 & 19.57 \\
Igun str & 13 & 28.26 \\
Oliha & 3 & 6.52 \\
Uselu & 6 & 13.04 \\
N'Benin & 9 & 19.57 \\
Ikpoba Hill & 2 & 4.36 \\
Ogiso & 4 & 8.70 \\
Total & 46 & 100 \\
\hline
\end{tabular}

The findings are some what in agreement with the views expressed by Engelhard (1982) and Falcons (1992) that the consumption of renewable energy sources like charcoal, is a major component of rural economics as well as energy needs. The involvement of people in the enterprise as a life supporting activity is geared to meet the need for additional manpower in forest based enterprises. This is because the World's consumption of energy of all kinds is increasing rapidly for the past decades which makes the renewable energy to become increasingly important (Pound,1981) This is because forest in Edo state plays the role of custodian of a state fund especially in the internal revenue generation

Some uses of charcoal for rural energy needs: Charcoal energy (cooking) is of particular important, since it yields higher fuel efficiency than wood. The variation between the seven identified uses ranged from domestic cooking to small cottage industries like suya preparation, Black Smiting and Bronze casting (Table 2) may be due to a combination of economic and occupational considerations. The results showed that the use of charcoal for roasting of maize dominated other uses considered in the study, hence accounted for $32.75 \%$. Suya preparation and general cooking of food accounted for $13.70 \%$ and $16.13 \%$ respectively, while roasting of plantain was the least $(8.19 \%)$. However, the use of charcoal for the supply of energy for cottage industries was more pronounced in Suya preparation than Black Smiting 
and Bronze casting combined together, since they accounted for $13.70 \%$ and $9.84 \%$ respectively. This result can not be overemphasized because the use of charcoal for Bronze casting is mostly taking place at Igun street in the Benin metropolis while other uses cut across other locations.

Table 2. Uses of Charcoal in Benin City (\%)

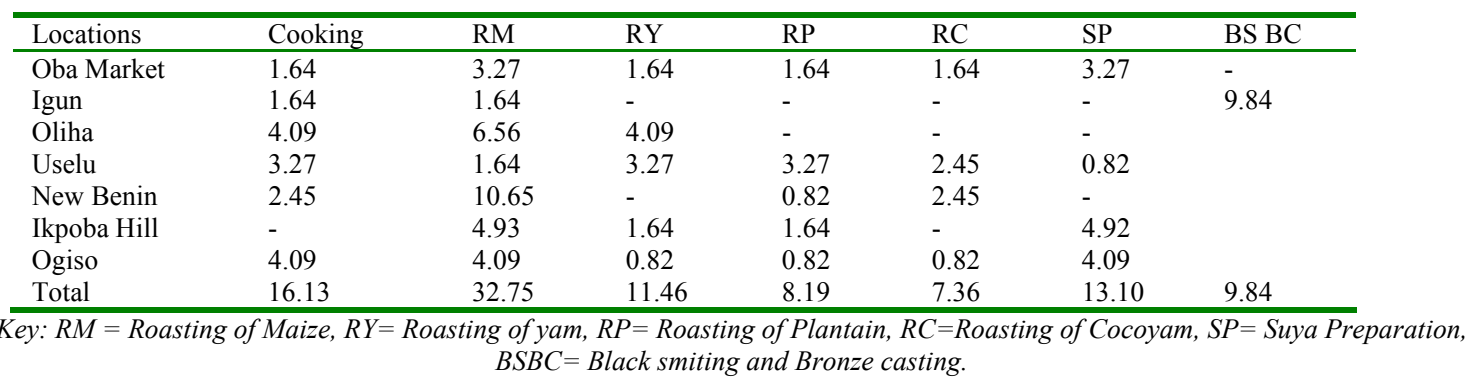

Therefore, it was observed that the uses of charcoal for activities that generate income dominate ordinary domestic purposes. This aptly corroborates the views expressed by authors like, Englehard (1982) and Dunn et al, (1983) who noted that renewable energy source contributes significantly to rural economies of the least developed countries ( LDCs) of which Nigeria is one of them.

Reasons for using charcoal as an energy source: Table 3 presents data on reasons for using charcoal to generate energy for both domestic \& commercial food preparation and for cottage industries, the five reasons identified by the respondents were convenience, relatively cheap with respect to petroleum products, smokeless ness, availability and efficiency. The result of analysis of variance (ANOVA) revealed that there were no significant differences $(\mathrm{P}>0.05)$ among the reasons considered in the study.

Table 3 Reason for using Charcoal as an energy source

\begin{tabular}{llllll}
\hline Locations & Convenience & Cheap & Smokelessness & Availability & Efficiency \\
\hline Oba Market & 8.13 & 9.98 & 11.54 & 8.13 & 12.92 \\
Igun & 11.54 & 9.98 & - & - & 15.34 \\
Oliha & 9.98 & 8.13 & 9.98 & - & 11.54 \\
Uselu & 9.98 & 8.13 & - & 8.13 & 8.13 \\
New Benin & 15.34 & 8.13 & - & 8.13 & 8.13 \\
Ikpoba Hill & 11.54 & - & 12.92 & - & 11.54 \\
Ogiso & 9.98 & - & - & 9.98 & 9.98 \\
Total & 76.49 & 44.35 & 47.36 & 36.22 & 84.79 \\
Means & 10.93 & 7.39 & 11.84 & 9.06 & 12.11 \\
\hline
\end{tabular}

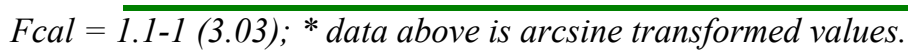

The finding can not be unconnected with the fact that the identified reasons contribute equally in attracting consumers for the usage of the products. The findings also corroborate the view expressed by BulaghSingala (1983) that charcoal stove has fuel efficiencies of $25-35 \%$ whereas wood stove is about $10 \%$ efficient.

Weekly sales of charcoal: The data on the weekly sales of charcoal ranged from N2000 to above N6000 are summarized (Table 4). ANOVA was undertaken on arcsine transformed percentage of the final count of the data showed no significant difference among various ranges at $5 \%$ level. The indication was that the average sale volumes among the charcoal sellers in the various locations within the study area were somewhat uniform. Thus, it was revealed that customers who use the product exhibit a steady patronage despite the volume of sales peculiar to a given location being considered.

Table.4. Weekly sales in Charcoal in Enterprises (N'000)

\begin{tabular}{lllll}
\hline Markets & $<2000$ & $3000-4000$ & $5000-6000$ & $>6000$ \\
\hline Oba Market & 8.13 & - & - & 5.74 \\
Igun & 15.34 & - & 9.98 & 11.54 \\
Oliha & 9.98 & - & 8.13 & 5.74 \\
Uselu & 9.98 & 8.13 & 8.13 & 5.74 \\
\hline
\end{tabular}




\begin{tabular}{lllll}
\hline New Benin & 14.18 & & 5.74 & 11.54 \\
Ikpoba Hill & 9.98 & 5.74 & 5.74 & 8.13 \\
Ogiso & 9.98 & - & - & - \\
Total & 77.57 & 13.87 & 37.72 & 48.43 \\
Means & 11.08 & 6.94 & 7.54 & 8.07 \\
\hline
\end{tabular}

Fcal $=0.34$

The two seasons in the year (raining \& dry) present district profit levels, and various ranges in naira bill which are summarized in Table 5.

Table 5. Weekly profits from Charcoal enterprises (N'00)

\begin{tabular}{|c|c|c|c|c|c|c|c|c|c|c|}
\hline \multirow{2}{*}{ Markets } & \multicolumn{2}{|c|}{$1-5$} & \multicolumn{2}{|l|}{$6-10$} & \multicolumn{2}{|l|}{$11-15$} & \multicolumn{2}{|l|}{$16-20$} & \multicolumn{2}{|l|}{$>21$} \\
\hline & $\mathrm{a}$ & b & $\mathrm{a}$ & b & $\mathrm{a}$ & b & $\mathrm{a}$ & $\mathrm{b}$ & $\mathrm{a}$ & $\mathrm{b}$ \\
\hline Oba market & & 5.26 & & 15.79 & 3.03 & & & & 12.12 & \\
\hline Igun & & 10.53 & 6.06 & 5.26 & 9.09 & 5.26 & & & 6.06 & 5.26 \\
\hline Oliha & & 5.26 & 3.03 & & 3.03 & & & & 6.06 & \\
\hline Uselu & & & 3.03 & & & & 5.74 & & 12.12 & 10.53 \\
\hline New Benin & & & 3.03 & 10.53 & & 5.26 & 11.54 & & 9.09 & \\
\hline Ikpoba Hill & & & 3.03 & & & 5.26 & 8.13 & & & \\
\hline Og Ogiso & & 10.54 & 6.06 & & & & & & 3.03 & \\
\hline Total & & 36.85 & 24.24 & 31.58 & 15.17 & 15.78 & 48.43 & & 48.48 & 15.79 \\
\hline
\end{tabular}

Key: $a=$ Rainy season profit; $b=$ Dry season profit

The weekly profit of over $\$ 2000$ was recorded in the rainy season dominated other profit ranges since $48.48 \%$ of the respondents affirmed that they made such an amount of money during the period. However, the least profit made in the rainy season was between $\$ 600$ - $\$ 1000$ was confirmed by $24.24 \%$ respondents. In case of dry season, the highest profit over $\$ 2000$ was only made by $15.79 \%$ of the respondents. It was in the dry season that the least profit of between $\$ 100-\mathrm{N} 500$ was made by $36.85 \%$ of the respondents. One of the major motives for establishing an enterprise is to make profit because no business is set to make loss it is the same profit that makes an individual to remain in an enterprise like charcoal despite the periods of socks and booms that characterize any business.

Distribution Channel of charcoal/supplies of charcoal: The charcoal distributions system links the charcoal supplier and the consumer, because like every other product; charcoal is of little use to the consumer, if it is not available at the right price, right place and time especially during scarcity, of petroleum products. Charcoal consumer in Benin City uses the product as a source of energy for both domestic and commercial food preparation as well as cottage industries through the identified distribution system

Table 6. Distribution channel of charcoal/ supplies of charcoal to consumers

\begin{tabular}{llll}
\hline Locations & Retails & Wholesale & Producer \\
\hline Ogiso Market & 14.18 & 18.44 & 8.13 \\
Ikpoba Hill & 20.27 & 12.92 & 8.13 \\
New Benin & 17.46 & 17.46 & 5.74 \\
Uselu & 18.44 & 12.92 & 5.74 \\
Siloko & 16.43 & 16.43 & - \\
Igun & 14.18 & 14.18 & 14.18 \\
Oba Market & 21.90 & - & 9.98 \\
Total & 124.86 & 92.35 & 51.90 \\
Mean & $17.84 \mathrm{a}$ & $15.38 \mathrm{~b}$ & $8.65 \mathrm{c}$ \\
\hline \multicolumn{4}{c}{ Fcal. $19.59>5.42$} \\
\hline
\end{tabular}

The data on retailer, wholesaler and producer reflect the distribution channel is presented in Table 6 . ANOVA was under taken on arcsine transformed percentage of the final count of the data indicated significant difference $(\mathrm{P}<0.05)$ among the three distribution channels identified in the study. Further analysis using fisher's least significant differences (LSD) revealed that retail was the dominant channel of distribution of the products for the various 
categories of the consumers that use the product for various purposes.

. In the same vein, the wholesale distribution channel was also more dominant than the producer's channel. The findings corroborate the views expressed by Rajagopal (1983) who noted that distribution channel is the foundation of the marketing system which makes for smooth flow of goods which has characteristics of desired direction, promptness and efficiency.

Conclusion: The study has confirmed some socioeconomic benefits associated with charcoal enterprises, despite its traditional production level and imbedded imperfect marketing nature of the product. The enterprise plays important roles in rural economies and also acts as significant substitutes to possible energy source, which is unpredictably available. The enterprise creates varied employment openings, since there are many people who are involved in various aspects of the enterprises which vary from one location to another. The study pinpoints various uses of charcoal ranging from domestic cooking of food to cottage industries like Suya preparation as well as Black Smiting and Bronze casting. The use of charcoal is one of the ways in which reliance of imported fossil fuel can be reduced (Dunn et al, 1983). Some reasons why people prefer to using the product as an energy source are identified as: convenience, relatively cheap, smokeless ness, availability and efficiency. The enterprise generates regular profit which is high and low during the rainy and dry seasons respectively. Thus, a greatly increased research effort is needed to illuminate the current situation of charcoal enterprises and also create various opportunities to ensure sustainable development of renewable energy resource like charcoal business.

Acknowledgements: We wish to acknowledge the contribution of field assistants; $\mathrm{Mr}$ Abedinigo Gbarway and Kinsley Uti who assisted in the administration of questionnaires. We are also thankful to Forestry and Wildlife Department for creating enabling environment and the conducive atmosphere for the study to be conducted.

\section{REFERERENCES}

Bulaghsingala, S S (1983) Charcoal: An alternative renewable energy Source. in the 1990s and beyond. In proc. of regional Symposium. Association of Franco-Ceylonese technologists and Indo-French Technical Association. Colombo, Srilanka.

Dunn, P D Samootsakoru; P Tuntawiroon, N (1983) Alternative Renewable energy sources for Rice production. Thailand, UK Agricultural system VII (4), 195 -209pp.

FORMECU (1999) Forest Resources study: Revised Forest management Plan of Edo State. 126.

Engelhard, J R (1992) Wood Energy Policy Development: Lessons from Kenya, In: Nemetz, N P (ed) Emerging issues in Forest Policy, UBC Press, Vancouver, 497-504pp.

Hannagan,J T (1980) Mastering statistics, $2^{\text {nd }}$ Edition, Macmillan Education Ltd, London, $606 \mathrm{p}$.

Holmes, H (1998) what is charcoal, Http//www. Discovery. Ecom/egi-bin/Image map/mapdin/genericanavban map.

Natural Resources Institute (1992) Wood Carbonization Unit: Design and development of a prototype with recovery of waste heat, Chatham Main time, Kent, United Kingdom,20p.

Pounds, N (1981) success in Economic Geography, John Murray Publishers Ltd, Edwards, J (ed). London, 372p.

Rajogopal, S V (1983) Selection channels of distribution for fertilizers, Agro-Chemical, FADINAP/FAI, special issue, $59-65 \mathrm{pp}$. 